\title{
Language Management in a Seventh-Day Adventist Church in the City of Maroua: Default Language Policy and Historical Factors
}

\author{
Francois Baïmada Gigla \\ Higher Teachers' Training College, The University of Maroua, Maroua, Cameroon
}

Email address:

baimada.gigla@gmail.com

\section{To cite this article:}

Francois Baïmada Gigla. Language Management in a Seventh-Day Adventist Church in the City of Maroua: Default Language Policy and Historical Factors. International Journal of Language and Linguistics. Vol. 8, No. 4, 2020, pp. 158-163. doi: 10.11648/j.ij11.20200804.16

Received: June 29, 2020; Accepted: July 13, 2020; Published: August 4, 2020

\begin{abstract}
This paper looks into language management and factors affecting language use in a Seventh-Day Adventist Church in the city of Maroua. The methodology consists of observation followed by a pre-prepared questionnaire supplemented with personal interviews with church faithful and rulers. The approach used to analyse the data is the structuralfunctional approach propounded by Kouega (2008) and successfully applied to some Christian Churches and to Islam. The findings show that, contrary to previous works, this Seventh-Day Adventist Church adopts only a default language policy as its religious language management strategy. The use of Fulfulde and French as the two default languages was found to be motivated by the wish to follow a neutral policy due to cosmopolitanism of the polity but also to keep the historical tradition. This policy is in total contradiction with what obtains in Catholic masses whose language policies were deeply influenced by the resolutions Council Vatican II authorizing the use of vernaculars in religious services and in Protestant churches where the sociolinguistic identities of the worshipers matter in the choice of the language in which some activities should be conducted.
\end{abstract}

Keywords: Language Management, Fulfulde, French, Seventh - Day Adventist, Maroua

\section{Introduction}

The thematization of the interplay between language and religion is not new in the field of sociolinguistics. Stewart (1962) considers the religious language function as one of the ten language functions [1]. The religious language function is the use of language primarily in connection with the ritual of a particular religion. The study of the relations between language and religion was boosted by Fishman, especially after the publication of his Explorations in the Sociology of Language and Religion in 2006 [2].

Religious language policy really got into its stride thanks to the interest of some key papers and books [3] by famous authors like Fishman, Omoniyi and Spolsky. The publication of Spolsky's Language Policy (2004) and quite recently his Religious Language Policy (2009) gave this sub-field of sociolinguistics an impetus [4]. In 2010 Tope Omoniyi edited a volume on The Sociology of Language and Religion: Change, Conflict and Accommodation. Most of the views of this volume express the role that language plays in shaping, constructing and disseminating religion and religiousness [5]. The growing interest in this field led Fishman to plead for a theoretical anchorage, a framework in which the many works conducted in this vibrant field of study can be grounded. Spolsky (2006) developed a framework which consists of four dimensions, notably: effects of religion on language, the mutuality of language and religion, effects of language on religion, language, religion and literacy [6]. Each of these four dimensions of the proposed frame consists of possible research foci and topics, which Spolsky identifies as potential researchable topics. The challenge of finding an appropriate theoretical framework is taken up by researchers all over the world. Today, the field of religious language policy is experiencing vibrant developments. The most challenging question is to come up with a theoretical framework which will be appropriate to all religions and religious denominations. This question is still to be answered, for not all three religions of the Book (Judaism, Christianity and Islam) follow the same language policy. Moreover, issues of literacy in the religious language or the language used for 
specific rituals, cosmopolitanism, rurality, historical factors, etc. make it difficult to use one and the same frame for all religions and at all places.

In Africa where the study of language and religion is gaining ground, Cameroon has been on the fore for the last twelve years. The publication of Kouega (2008) which looked into language use in an urban Catholic Church in Yaoundé [7], the capital city of Cameroon set the scene for a thought-provoking series of papers and books in connection to religious language management. A good number of papers have used different case studies to account for the interplay between language and religion and to try to determine the language policy used by each religion or church. Christianity occupies the leading position in this wise. Kouega (2008) which based on the Catholic Church has triggered the interest of many papers on language use in Christianity. Kouega and Ndzotom (2011a, 2011b) Kouega and Emaleu (2013) [10] focused on protestant and Pentecostal churches [8, 9], while Kouega and Baimada (2012) and Baimada 2013, 2018b and 2020a) look into Islamic language policy [11-14]. This notwithstanding, one component of Christianity seems to have been left out.

The present paper examines language use in the SeventhDay Adventist Church with the intention to determine how this Christian religious denomination manages linguistic resources. It bases on an urban church in the city of Maroua in a bid to make use of the very important variable of cosmopolitanism which is so dear to sociolinguistic studies. As a result, the context as well as the background need to be well carved.

\section{Background to the Seventh - Day Adventist Church in the City of Maroua}

The advent of the Seventh-day Adventist Church in the Far North Region of Cameroon in general and in the city of Maroua in particular dates back to the year 1928 with the arrival of Ruben Bergström a Missionary of Swedish descent who went from Sweden to Northern Cameroon through neighboring Nigeria with the intention of converting several pagan tribes known under the collective name of Kirdis (keer-dee). Existing literature on these people describes them as being extremely hostile to the then French colonial government, and, owing to the mountainous nature of their country, were long able to resist foreign rule. They were generally regarded as being the most difficult of all tribes in French African territory. For about a century, they had staunchly resisted Moslem influences and had shown themselves suspicious of all foreigners.

When he arrived Maroua in 1928, Ruben Bergström first asked the Lamido of Maroua for some space to settle. He was given a slot at Balaza, a small village East of the city of Maroua were he learnt local Fulfulde and started evangelizing. After his house was burnt down to ashes, he left for Mambang, still in the outskirt of the city of Maroua, this time around in a Kirdi village. Bergström settled at Dogba in1930, a hamlet located northward in the outskirts of the city of Maroua where he opened the first of all mission stations in Northern Cameroon. He had mastered enough Fulfulde and was able to preach in it. Given that the local Kirdi people spoke different languages, Fulfulde and French were the languages used in preaching. As the Seventh - day Adventist Church was gaining ground among the Kirdi people, the Chapels multiplied and extended to the Mandara Mountains to reach the Mada, Zulgo, Mora-Massif, Méri, Baldama ethnic groups. Due to lack of mutual intelligibility, the media of communication used were default languages, namely French and Fulfulde. The first evangelists trained by seventh-day Adventists were trained to evangelize in Fulfulde and French. Today, these two languages are the main (and sometimes lone) tools used both in rural (district churches) and urban centers (federations). In the beginning, the use of Fulfulde was accounted for by the fact that the first converts spoke different languages and that it was quite impossible for the evangelists to be proficient in all those languages, hence the use of default languages. Today, this policy still holds sway.

\section{Methodology and Theoretical Framework}

This subsection looks into the methodology and the theoretical framework used in the present paper.

\subsection{Methodology}

The data were collected through various methods of including observation, a questionnaire, personal communications and communications with the faithful some Pastors. These are discussed below.

\subsubsection{Observation}

It was deemed necessary to attend some Saturday services in order to observe the way language (s) is/are used in this community. This even helped in identifying the various stages of the service and the languages used in each ritual.

\subsubsection{Questionnaire}

A seventeen-item questionnaire was designed and administered to Seventh Day Adventist faithful of the North Cameroon Federation. The questionnaire which was based on the various stages of the Saturday services aimed at 1) identifying the language (s) used in each ritual and 2) why they are used (motivations).

\subsubsection{Personal Communications and Interviews}

Some people who were identified as key people in the conduct of the rituals were interviewed. They were contacted after the services to answer some questions in the form of verbal communication.

\subsection{Theoretical Framework}

The theoretical ground used in this work is Kouega's 
(2008) structural-functional approach used in a good number of papers published in renowned international journals. Some of these papers include Kouega and Ndzotom (2011a, 2011b), Kouega and Baimada (2012), Kouega and Emaleu (2013), Ndzotom (2016), Baimada 2013). The structural-functional approach was also used in Ndzotom 2011 and Baimada (2013), two PhD Dissertations which were conducted on language use in Protestant Churches [15] and in Mosques, respectively [16]. This approach consists in segmenting services into its constituent parts and checking what language (s) is/are used and for what reason (factors motivating the choice of a given language).

\section{Results and Discussion}

Through observation and communication with a good number of faithful, it was found that a typical Saturday service consists of the following stages: Prayer, Canticles, First Reading, Invocations, Second Reading, Canticle, Pastoral prayer, offerings and tithes/dimes, Welcome and Presentation of visitors, Canticles/or choirs, Introduction of the Predicator by the Coordinator, Sermon with translator, Choir, Prayer and final blessing.

The questionnaire was devised on the basis of the segmentation of the service into these constituent parts as required by the structural-functional approach. The results and discussions follow that segmentation.

\subsection{Language used for the Rituals}

The key rituals and activities identified. The language (s) used for each ritual were identified and are presented.

\subsubsection{Language used for the Initial Prayer, Canticles, the First Reading, the Invocation, the Second Reading and the Second Canticle}

This sub-section looks into the languages used for the first six rituals of the Saturday service in the Seventh-day Adventist Church. The results are presented in the tables below.

Table 1 below indicates the language (s) used for the initial prayer.

Table 1. Language used for the initial prayer.

\begin{tabular}{ll}
\hline Activity & Language \\
\hline Prayer & French or Fulfulde \\
\hline
\end{tabular}

Table 2 indicates the language in which the canticles are performed.

Table 2. Language used for the Canticles.

\begin{tabular}{ll}
\hline Activity & Language \\
\hline Canticles & French or Fulfulde \\
\hline
\end{tabular}

Table 3 shows the language (s) used for the First Reading.
Table 3. Language used for the First Reading.

\begin{tabular}{ll}
\hline Activity & Language \\
\hline First Reading & French or Fulfulde \\
\hline
\end{tabular}

Table 4 below indicates the language in which the invocations are performed

Table 4. Language (s) used for the Invocations.

\begin{tabular}{ll}
\hline Activity & Language \\
\hline Invocations & French or Fulfulde \\
\hline
\end{tabular}

Table 5 below shows the language (s) in which the second Reading is performed

Table 5. Language (s) used for the Second Reading.

\begin{tabular}{ll}
\hline Activity & Language \\
\hline Second Reading & French or Fulfulde \\
\hline
\end{tabular}

Table 6 shows the language in which the second Canticle is sung.

Table 6. Language used for the second Canticle.

\begin{tabular}{ll}
\hline Activity & Language \\
\hline Second Canticle & French or Fulfulde \\
\hline
\end{tabular}

The languages used for the first six rituals (the Initial Prayer, Canticles, the First Reading, the Invocation, the Second Reading and the Second Canticle) were found to be French and Fulfulde as can be inferred from the results presented in the tables above. In some activities, either language was used while in others, only one was used.

\subsubsection{Language used for the Pastoral Prayer}

The pastoral prayer is performed either by an Elder of the Church or by a Deacon. The following table indicates the language in which it is performed.

Table 7. Language used for the pastoral prayer.

\begin{tabular}{ll}
\hline Activity & Language \\
\hline Pastoral Prayer & French or Fulfulde \\
\hline
\end{tabular}

\subsubsection{Language Used for Offerings and Tithes}

Loyalty services are marked by two important elements in the life of the Church, notably offerings and tithes. Table 8 below shows the language these rituals are conducted.

Table 8. Language used for offerings and tithes.

\begin{tabular}{ll}
\hline Activity & Language \\
\hline Offerings and tithes & French or Fulfulde \\
\hline
\end{tabular}

\subsubsection{Welcome and Presentation of visitors}

This stage consists in welcoming new faithful and presenting them to the community. Table 9 below indicates the language (s) used for this ritual.

Table 9. Language used for the presentation of visitors.

\begin{tabular}{ll}
\hline Activity & Language \\
\hline Welcome and Presentation of visitors & French or Fulfulde \\
\hline
\end{tabular}




\subsubsection{Canticle and Singing}

After presenting new-comers, either the whole community sings a Canticle or a song is sung by the Choir. The table below shows the language used for that ritual.

Table 10. Language used for Canticles and songs.

\begin{tabular}{ll}
\hline Activity & Language \\
\hline Welcome and Presentation of visitors & French or Fulfulde \\
\hline
\end{tabular}

\subsubsection{Introduction of the Predicator}

When the Canticle and the song are over, the Coordinator of the services introduces the predicator. This is done in one language as indicated in table 11 below.

Table 11. Introduction of the predicator.

\begin{tabular}{ll}
\hline Activity & Language \\
\hline Introduction of the predicator & French or Fulfulde \\
\hline
\end{tabular}

\subsubsection{Language Used for the Sermon}

After he is introduced to the community, the predicator performs the sermon. This is done in French or Fulfulde but requires a translation in one case or the other as indicted in table 12 below.

Table 12. Language used for the sermon.

\begin{tabular}{ll}
\hline Activity & Language \\
\hline Sermon & French or Fulfulde \\
\hline
\end{tabular}

\subsubsection{Language Used by the Choir}

When the sermon is over, the Choir sings a song. The language in which the song is sung is indicated in table 13 below.

Table 13. Language used by the Choir.

\begin{tabular}{ll}
\hline Activity & Language \\
\hline Song by the Choir & French or Fulfulde \\
\hline
\end{tabular}

\subsubsection{Language Used for the Prayer}

After the song, there is a prayer. The following table indicates the language in which the predicator prays for the whole community.

Table 14. Language used or the final prayer.

\begin{tabular}{ll}
\hline Activity & Language \\
\hline Prayer & French or Fulfulde \\
\hline
\end{tabular}

\subsubsection{The Final Blessing}

The last ritual of the Saturday Service is the final blessing by the Celebrants. The table below indicates the language in which it is performed.

Table 15. Language used for the final blessing.

\begin{tabular}{ll}
\hline Activity & Language \\
\hline Final Blessing & French or Fulfulde \\
\hline
\end{tabular}

The fifteen key rituals of the religious worship were thus identified alongside the language (s) used for each of them. The paper also sought to find out what motivated the use of these languages.

\subsection{Factors Affecting the Use of a Language}

Two factors were found to affect the choice of a language for a given activity. These factors are taken in turn under 4.2.1 and 4.2.2 below.

\subsubsection{Neutrality Through Default Language Policy}

The use of French and Fulfulde in the key activities of the Saturday Service was partially accounted for by the fact that the Church has opted for a neutral policy. In effect, through observation and communication with some faithful and celebrants, it was noted that due to the linguistic plurality observed among the members of the Seventh-day Adventist Church of the North Federation in Maroua, it was deemed wise to follow a neutral policy whereby no member should feel frustrated by the choice and use of a given language. The Celebrants indicated that the faithful come from various ethnolinguistic origins as can be portrayed by the observable cosmopolitanism of the city of Maroua (Seignobos and Iyebi Mandjeck 2004 [17] and Maud Lasseur 2004) [18].

This resulted in the choice of French, primarily because the people attending the Saturday Service in this church are among the most educated of the whole Region of the Far North Cameroon. Secondly, Fulfulde was also found to be an appropriate default-language due to the fact that it is a vehicular language in the area and many more faithful are proficient in it.

Besides, some of the Pastors, elders and Celebrants who were contacted are more proficient in Fulfulde than French. The availability of religious documents in Fulfulde shows that the Seventh-Day Adventist Church and Fulfulde have a longstanding relation in this part of the country. It was even recorded that the first Adventist Pastors in this part of the country were proficient in Fulfulde which in those days was the only tool for cross-linguistic communications in the linguistically diversified Northern Cameroon. Apart from neutrality, language choice was found to be motivated by historical factors in relation to Fulfulde in this part of the country.

\subsubsection{Historical Factors}

Historical factors were also found to have a say in the choice and use of Fulfulde in the statutory rituals of the Church. Through library and internet searches, communication with some elders and Pastors, it was found that the use of Fulfulde in the rituals of the Seventh Day Adventist Church dates back to the very first days of this Church in Northern Cameroon which was then (and still is) highly dominated by the overwhelming presence of Fulani rule on the (socio) linguistic, cultural and to some extent, islamic rostrum. Dogba, the most historically relevant place in the history of the Church is in this wise indicative of the role Fulfulde has played in the Adventist Church. The same can be said for Dargala, a locality in the Diamare Division which is full of history.

The very first converts were not from the Fulani ethnic group, but from diverse linguistic backgrounds. Though they were under the rule of the Lamido who is from the Fulani 
aristocracy, not all the subjects were Fulani. The bulk of the faithful came from the neighboring mount Mandara Mountains, while the natives (mostly the Guiziga people) were already under the dominance of the Fulani, following the Jihad which paved the way for the new order, placing Muslim aristocracies at the helm of many cities. The use of Fulfulde is due to the close development the Church has had in its early days of existence in the Far North Region. As a matter of fact, the first Pastors, Elders and Deacon were not proficient in French as they did not have western education. They were rather trained to be Pastors in Fulfulde. This explains why a good number of them still conduct their rituals in this language, while others do it in French. Most of those who use Fulfulde specifically are now on retirement.

\section{Conclusion}

In a nutshell, this paper has looked into language use in a Seventh-Day Adventist Church with the intentions to identify the languages used and to determine the factors affecting their uses as proposed by the structural-functional approach. It was found that two default languages, namely Fulfulde and French (which is not a native language in that part of the country) were used as tools for communication in a bid to avoid any biased choice (which could be the language of the Celebrant or that of the largest community of faithful as was found in Kouega 2008). This default language policy is in total adequacy with the requirements of language management in pluralistic settings. Indeed, language choice and use in multilingual polities requires well-thought policies which should help maintain balance among the diversity. History was also found to be a factor affecting the choice of Fulfulde in so far as the availability of materials (translated religious documents) in Fulfulde and the parallel evolution of Fulfulde and the Seventh-Day Adventist Church in Northern Cameroon play in favour of the use of Fulfulde because of its vehicular capacities. These two factors help solve the problem of "what language must be chosen" in multilingual and culturally diversified contexts like the Church where the faithful come from all ethno-linguistic identities. In this wise, the Far North Region of Cameroon which is known for its high linguistic diversity can take advantage of the existence of Fulfulde as a vehicular language to solve or anticipate on potential selfish considerations in line with the choice of a medium of communication for out-group needs. If this can successfully operate in a church, it can also function in larger macro-sociolinguistic settings. This notwithstanding, the overwhelming presence of vehicular languages in religious practices in general and in the Seventh-Day Adventist Church can be seen as a threat to minor and minority languages. The use of vehicular languages reduces diversity, giving ethnic languages no chance to survive beyond the family level which in urban centres is their only space of expression. This aspect of religious language management deserves more attention from researchers, for it brings together the key concepts of native language (re) vitalization and religious language management in pluralistic contexts.

\section{Appendix}

Sample questionnaire

This questionnaire aims at collecting data on the language (s) used for each religious ritual during the Saturday service in the Seventh Day Adventist Church. Thank you in advance for filling in.

Q1: In what language was the prayer made?

Q2: In what language were the Canticles sung?

Q3: In what language the First Reading done?

Q4: In what language was the invocation made?

Q5: In what language was the second reading done?

Q6: In what language was the canticle sung?

Q7: In what language was the pastoral prayer performed?

Q8: In what language were the offerings and tithes conducted?

Q9: In what language were the visitors welcomed and presented

Q10: In what language were the Canticles sung?

Q11: In what language did the Coordinator introduce the Predicator?

Q12: In what language was the sermon made?

Q13: In what language did the Choir sing?

Q14: In what language was the prayer made?

Q15: In what language did the predicator performed the final blessing? 
Q16: What motivated the use of these languages?

Q17: What other factors affected the use of a language for a given ritual?

\section{References}

[1] Stewart, W. A. (1962). An Outline of Linguistic Typology for Studying Multi-linguicism. In F. Rice (Ed.). Study of the role of second languages in Asia, Africa and Latin America, 15-25. Washington DC: Center for Applied Linguistics.

[2] Fishman, Joshua A. (2006). 'A Decalogue of Basic Theoretical Perspectives for a Sociology of Language and Religion', in Tope Omoniyi and Joshua A. Fishman (eds), Explorations in the Sociology of Language and Religion, Amsterdam/ Philadelphia: John Benjamins Publishing Company, pp. 13-25.

[3] Spolsky, B. (2004) (2004). Language policy. Cambridge: Cambridge University Press.

[4] Spolsky, B. (2009). Language management. Cambridge. Cambridge University Press.

[5] Omoniyi, Tope and Fishman, Joshua A. (Eds.) (2006): Explorations in the sociology of language and religion. Amsterdam: John Benjamins.

[6] Spolsky, Bernard (2006): Introduction. Part II. In: Omoniyi/ Fishman (Eds.), Explorations in the sociology of language and religion. Amsterdam: John Benjamins. 4-9.

[7] Kouega J. P. (2008). Language, religion and cosmopolitanism: language use in the Catholic Church in Yaoundé - Cameroon. International Journal of Multilingualism, 5 (2), pp. 140-153.

[8] Kouega, J. P., and Ndzotom Mbakop A W. (2011a). Multilingual practices in Presbyterian churches in Cameroon. International Journal of Innovative Interdisciplinary Research Issue 1 Dec 2011, pp 44-58.

[9] Kouega, J. P., and Ndzotom Mbakop A W. (2011b). Language use in multi-ethnic Christian congregations: The case of the
Evangelical Church of Cameroon. Annals of the Faculty of Arts, Letters and Social Sciences, University of Yaoundé 13 (1), 67-86.

[10] Kouega J. P., and Emaleu, C. (2013). Language choice in multilingual socio religious settings in southwest Cameroon. World Englishes 32 (3), pp. 403-416.

[11] Kouega, J. P., and Baimada Gigla F. (2011). Language use in the Islamic faith in Cameroon: The case of a mosque in the city of Maroua. Journal of Language and Culture, 3 (1), pp. 10-19.

[12] Baimada Gigla F. (2013). Language use in the Islamic Faith in the three northern regions of Cameroon, $\mathrm{A} \mathrm{PhD} \mathrm{research}$ project, University of Yaoundé I.

[13] Baimada Gigla F. (2018b). Language Practice in Multilingual Islamic Northern Cameroon. In Martha Moore (Ed.), Exploring Religious Beliefs and Practices from around the World. Pp. 85-128. New York: Nova Science Publishers.

[14] Baimada Gigla F. (2020a). Current Approaches to Religious Language Management in Multilingual Africa; In Clément Dili Palai Patrimoine (s) Mémoire (s) et Identité (s) en Afrique. Yaoundé: Denimber and Larimber Pp 102-116.

[15] Ndzotom Mbakop, Antoine Willy (2011). Multilingualism and religion. Language use in Protestant churches in Cameroon: the case of the city of Yaoundé. Unpublished PhD dissertation, The University of Yaoundé 1.

[16] Ndzotom Mbakop, Antoine Willy (2016). Language choice in multilingual religious settings: The historical factor. Pragmatics and Society, 7 (3), 413-435.

[17] Seignobos, C. and Iyebi-Mandjeck O (2004). Atlas de la Province de l'Extrême-Nord Cameroun. Paris: IRD.

[18] Maud Lasseur (2005). Cameroun: les nouveaux territoires de Dieu. In Afrique Contemporaine, (3), 125, pp. 93-116. 